Original article

\title{
In vivo antimicrobial inhibition of Punica granatum extracts as mouthwash
}

\author{
Dhifaf M. Al-Obaidi ${ }^{1}$, Saja A. Muhsin ${ }^{2}$, Afnan A. Ibrahim ${ }^{1}$ \\ ${ }^{1}$ Baghdad University, Baghdad, Iraq \\ ${ }^{2}$ Middle Technical University, Baghdad, Iraq
}

Received 17 June 2017, Revised 19 July 2017, Accepted 28 July 2017

(C) 2017, Al-Obaidi D.M., Muhsin S.A., Ibrahim A.A.

C 2017, Russian Open Medical Journal

Abstract: Background - Complex polysaccharides have been detected and characterized in Punica granatum or pomegranate constituents who may act as fungal and bacterial inhibitor as well as an anti-inflammatory effect. However, limited studies were reported on using pomegranate extracts as an anti-bacterial mouthwash.

Objectives - To determine the effect of Punica granatum (pomegranate) extract on microbial activity of some bacterial genus isolated from the mouth.

Material and Methods - This study included preparation of three different concentrations of Punica granatum methanolic extract of $25 \%$, $50 \%$, and $75 \%$. The inhibition activity of these extracts was tested on different strains such as Sm, Sa, Ec, Kp, Sg and Sf.

Results - Results exhibited an effective inhibition of pomegranate extracts against most of the tested strains which were isolated from patients' mouths. The $50 \%$ and $75 \%$ concentrations of methanolic extract exhibited significant inhibition against four tested strains compared to mouthwash $(\mathrm{P} \leq 0.05)$, while the $25 \%$ concentration was less effective than the other concentrations and its antibacterial effect was non-significant in comparison with the mouthwash.

Conclusions - This study indicates the inhibitory effectiveness of Punica granatum extracts of high percentage on microbial activity of some bacterial genus isolated from patients' mouths and suggests the possibility prepare a mouthwash from pomegranate extract.

Keywords: Punica granatum extract, microbial activity, inhibition, mouthwash, isolated bacterial genus.

Cite as Al-Obaidi DM, Muhsin SA, Ibrahim AA. In vivo antimicrobial inhibition of Punica Granatum extracts as mouthwash. Russian Open Medical Journal 2017; 6: e0403.

Correspondence to Saja A. Muhsin. Address: Prosthetic Dental Technology, College of Health and Medical Technology, Middle Technical University, Baghdad, Iraq. E-mail: dr.sajaalshimmary@gmail.com.

\section{Introduction}

On the basis of their medicinal properties herbs have been used in traditional medicine for many years and reported phytochemical and pharmacological studies support their traditional usage and they have also proved to be useful for clinical studies and development of commercial drugs [1-3].

Several medicine systems have been used the Punica granatum (pomegranate) for its therapeutic properties and indicated antibacterial activity as among its biological properties [4-7]. The pomegranate or Punica granatum is the predominant member of two species comprising the Punicaceae family [6]. It is considered as "a pharmacy unto itself" and is used as an antiparasitic agent $[5,8]$. Historically, the pomegranate was used in different areas of systematic medicine and with variable elements, for example in Ayurvedic blood tonic [9], and to heal apathy, diarrhea, and ulcers.

The potential therapeutic properties of pomegranate are wideranging and include treatment and prevention of cancer, cardiovascular disease, diabetes, dental conditions, erectile dysfunction, and protection from ultraviolet (UV) radiation. Other potential applications include infant brain ischemia, Alzheimer's disease, male infertility, arthritis, and obesity [10]. Furthermore, pomegranate constituent applications have been used for their anti-inflammatory properties to treat dental conditions, bacterial infections, antibiotic resistance, diarrhea dysentery and intestinal parasites [11-13], in addition to the use of antimicrobial properties of the juice against $E$. coli, Bacillus subtilis [11].

Pomegranate peel is recognized for its many health promoting qualities and apparent wound healing properties [14]. Extract of Punica can be used as a germicide especially in vaginal infection and treatment of some intestinal worms [15-17]. Pomegranate peels have been recognized for their significant health promoting qualities and healing properties, and are considered as important dietary sources of antioxidant phenolics. Moreover, evidence was reported of the presence of antimicrobial phenol compounds, and extract of Punica grantum cortex has exhibited inhibitory activity on the growth of some pathogenic bacteria isolated from the human stomach and intestine [18].

Pomegranate trees typically grow to a height of 12-16 feet, have many spiny branches and can be extremely long-lived, as evidenced by trees in Versailles, France, known to be over 200 
years old. The leaves are glossy and lance-shaped, and the bark of the tree turns gray as the tree ages. The flowers are large, red, white, or multicolored and have a tubular calyx that eventually becomes the fruit. The ripe pomegranate fruit can be up to five inches wide, with deep red and leathery skin, grenade-like in shape and crowned by the pointed calyx. The fruit contains many seeds separated by white, membranous pericarp, each of which is surrounded by small amounts of tart red juice [19]. The botanical name is Punica granatum, family name: Puniacaceal; common name: Pomegranate; and the seeds, flowers, and peels are the parts used in medicine [11-13]. Chemically pomegranate consists of eicosanoic, linolenic, conjugated, linolenic alpha, oleic, palmitic, punicic, stearic, citric and malic acids, phenolic compounds such as gallic, coumaric acid, catechin, phloridzin and quercetin, protocatechuic, chlorogenic, cafeic, and ferulic acid. The most therapeutically beneficial pomegranate constituents are ellagic acid, ellagitannins (including punicalagin), punicic acid, flavonoids, anthocyanidins, anthocyanins, and estrogenic flavonols and flavones [3]. The cortex of pomegranate contains alkaloids, tannins, phenols, flavonoids and saponins [20]. Punica peels contain glycosides and gall of pelletierine fungal and bacterial growth inhibition, the antimicrobial activity of pipe various degrees of inhibition against the growth of investigated microorganisms [21, 22]. Complex polysaccharides have been detected and characterized in the peels [23]. Therefore, this study aims to determine the effect of Punica granatum (pomegranate) extract on microbial activity of some bacterial genus isolated from the mouth.

\section{Material and Methods}

\section{Preparation of pomegranate powder}

Slices of the peel of $2 \mathrm{~mm}$ thickness were peeled from the external surface of Iraqi pomegranate fruit. The peels were dried in the shade for 30 days, ground and sieved into powder using a $250 \mu \mathrm{m}$ grit size sieve (Fieldmaster ${ }^{\circledR}$, USA). The dried powder was extracted using methanol solvent [24]. Chlorhexidine gluconate mouthwash (Corsodyl ${ }^{\circledR}$-GlaxoSmithKline, UK) was used as a control group.

\section{Preparation of methanol extract}

An extract solution was prepared using $100 \mathrm{ml}$ of methanol solvent liquid (AnalaR Normapur ${ }^{\circledR}$ VWR, UK) that was added to 25 $\mathrm{g}$ of pomegranate peel powder with shaking. The solution was left for $24 \mathrm{~h}$ for maximum powder dissolution in the solvent methanol. Then the mixture was filtered using Cellulose Filter Paper of grade 2 and $90 \mathrm{~mm}$ diameter (Whatman ${ }^{\circledR}$, England) to achieve an extract solution of $25 \%$. The procedure was repeated with $50 \mathrm{~g}$ and $75 \mathrm{~g}$ of pomegranate peel powder to gain extract concentrations of $50 \%$ and $75 \%$. An agar well diffusion method of $8 \mathrm{~mm}$ diameter cups was used to test the antimicrobial effect of these concentrations.

\section{Bacterial strains}

Different strains were used in the study such as Staphylococcus mutants, Staphylococcus aureus, Escherichia coli, Klebsiella pneumonia, Streptococcus gaseous and Streptococcus faecalis. Swabs were collected from patients suffering from caries and gingivitis, and the bacteria strains were isolated and diagnosed in the College of Science at Baghdad University (Baghdad, Iraq).
Table 1. Mean effects of Punica granatum extracts as antimicrobial inhibition mouthwash on some isolated bacteria

\begin{tabular}{ccccc}
\hline Bacteria & \multicolumn{4}{c}{ Tested zone of inhibition, mm, Mean \pm SD } \\
\cline { 2 - 5 } & $\begin{array}{c}\text { Chlorhexidine } \\
\text { (control) }\end{array}$ & $25 \%$ & $50 \%$ & $75 \%$ \\
\hline Sm & $14.16 \pm 0.54$ & 0 & $23.00 \pm 0.77$ & $20.33 \pm 0.42$ \\
Sa & $15.66 \pm 0.42$ & 0 & $22.50 \pm 0.42$ & $22.33 \pm 0.49$ \\
Ec & $13.00 \pm 0.57$ & $14.83 \pm 0.47$ & 0 & 0 \\
Kp & $13.00 \pm 0.81$ & 0 & 0 & 0 \\
Sg & $12.16 \pm 1.11$ & $15.83 \pm 0.47$ & $20.00 \pm 0.36$ & $17.83 \pm 0.98$ \\
Sf & $11.83 \pm 0.54$ & $16.33 \pm 0.33$ & $20.50 \pm 0.43$ & $19.66 \pm 0.42$ \\
\hline
\end{tabular}

Mean \pm SD, mean with standard deviation; Sm, Staphylococcus mutants; Sa, Staphylococcus aureus; Ec, Escherichia coli; Kp, Klebsiella pneumonia; Sg, Streptococcus gaseous; Sf, Streptococcus faecalis.

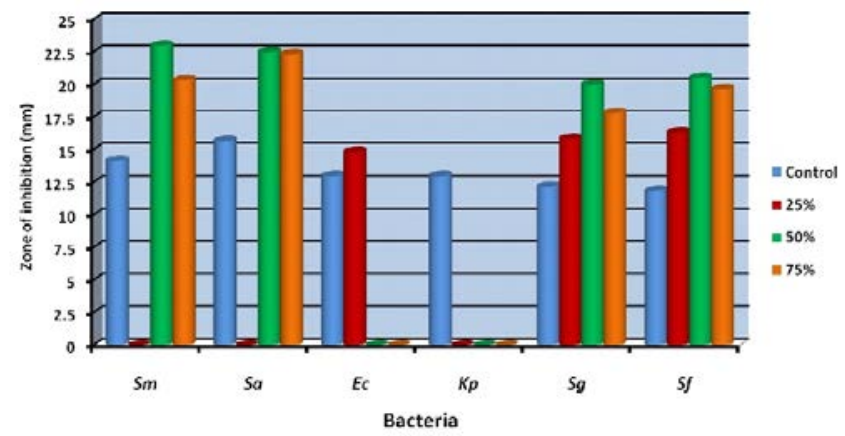

Figure 1. Diagram showing the mean distribution of Punica granatum methanol extracts as antimicrobial inhibitors.

Sm, Staphylococcus mutants; Sa, Staphylococcus aureus; Ec, Escherichia coli; Kp, Klebsiella pneumonia; Sg, Streptococcus gaseous; Sf, Streptococcus faecalis.

\section{Culture media}

MHA (Mueller-Hinton Agar) medium (HiMedia, UK) was used $[25,26]$. The medium was dehydrated, sterilized in an autoclave at $121^{\circ} \mathrm{C}$ for 15 minutes, poured into sterilized Petri dishes and allowed to set; the plates were then stored at $4-10^{\circ} \mathrm{C}$ in the refrigerator.

The antibacterial activity was tested using agar well method $(n=3)$. The dried plates were inoculated with test strains uniformly over the surface using a sterile cotton swab. $8 \mathrm{~mm}$ discs made by Cork Borer (Abron, UK) were loaded with the prepared extract and control solution, and after drying the plates were incubated at $37^{\circ} \mathrm{C}$ for $24 \mathrm{~h}$. The zone of inhibition of bacterial growth around the disc was measured in millimeters and recorded [27, 28]. Each plate contains 4 inhibition zones and the tests were repeated three times and the average diameter of the inhibition zone was recorded.

\section{Statistical method}

The statistical methods used to analyze the results of this study included analysis of variation (ANOVA-Tukey and Gemes Howel tests) [29]. The tests performed at a confidence level of 95\% $(P<0.05)$.

\section{Results}

The results in Figure 1, and Tables 1 to 3 indicated that the methanolic extract exhibited effective inhibition against the tested 
strains. $25 \%$ concentration of methanolic extract demonstrated low inhibition while those of $50 \%$ and $75 \%$ exhibited high inhibition against the strains. The antibacterial effect of the methanolic extract was more effective than the Chlorhexidine gluconate mouthwash which displayed a low inhibition zone against the tested bacterial strains.

The most effective concentration of Punica granatum extract was on Streptococcus mutants bacteria at $50 \%$ concentration, and this was significantly more effective than the mouthwash. Bacterial growth was not inhibited by $25 \%$ concentration of Punica extract, although the extract was more effective on this bacterium than the mouthwash concentrations of $50 \%$ and $75 \%$.

Punica granatum extract concentrations of $50 \%$ and $75 \%$ were both significantly more effective in their inhibitory action against Staphylococcus aureus bacteria, while that of $25 \%$ had no inhibitory action. On the other hand, the inhibitory action of the $25 \%$ extract concentration was more effective than the mouthwash on Escherichia coli bacteria.

Generally, there were statistically significant differences $(P<0.05)$ with all the Punica granatum extract concentrations and they were more effective than the mouthwash, particularly against the growth of Streptococcus gaseous.

\section{Discussion}

All concentrations of the extract were more effective than the mouthwash, with significant differences against Streptococcus faecalis bacteria, the higher concentration having a significantly larger inhibition zone at $(\mathrm{P}<0.05)$. As indicated in other studies' findings, the significant inhibitory effect of pipe could be increased by increasing the concentration of alcoholic extracts [21, 22]. The highest inhibition was obtained for $E$. coli. On the other hand, the mouthwash was more effective in its inhibitory action against Klebsiella pneumonia, whilst the extract had little effect.

Medicinal plants still play a vital role in meeting basic health needs in developing countries. Nearly $80 \%$ of the world's population rely on traditional medicine for primary health care, most of which involves the use of natural products, and plants continue to be a rich source of therapeutic agents [30-32]. Many researchers have conducted extensive studies of the biological properties of Punica granatum and their results showed that this plant is ethno medically valuable $[24,33]$. The extent of the inhibitory effect of the pomegranate extracts could be attributed to the phenolic and anthocyanin content of the fruit. The bioactivity of Ariel extracts on the microorganisms tested exhibited high total flavonoid, phenolics, anthocyanins and organic acid concentration [34]. Tesaki et al. confirmed that phenolics were the most important compounds against bacteria, and among the Gallic acid was identified as the most active compound for inhibition of bacteria [35].

The inhibitory effect of phenolic compounds could be explained by absorption to cell membranes, interaction with enzymes, substrate and metal ion deprivation [36]. The high levels of phenolic compounds exhibited effective antimicrobial properties. Antimicrobial phenolic compounds can degrade the cell wall, disrupt the cytoplasmic membrane, damage membrane proteins and cause interference that eventually leads to cell death [37].
Table 2. The significance of different Punica granatum extracts among isolated bacteria

\begin{tabular}{|c|c|c|c|c|c|}
\hline \multicolumn{2}{|c|}{ Bacteria } & \multicolumn{4}{|c|}{ Treatment (P-value) } \\
\hline \multirow[t]{2}{*}{ (A) } & \multirow[t]{2}{*}{ (B) } & \multirow{2}{*}{$\begin{array}{l}\text { Chlorhexidine } \\
\text { (control) }\end{array}$} & \multicolumn{3}{|c|}{ Punica granatum extract } \\
\hline & & & $25 \%$ & $50 \%$ & $75 \%$ \\
\hline \multirow[t]{5}{*}{$\mathrm{Sm}$} & Sa & ** & * & ** & ** \\
\hline & Ec & ** & * & * & * \\
\hline & Kp & ** & * & * & * \\
\hline & Sg & $* *$ & $*$ & $* *$ & $* *$ \\
\hline & Sf & $* *$ & $*$ & $* *$ & $* *$ \\
\hline \multirow[t]{4}{*}{$\mathrm{Sa}$} & Ec & $* *$ & $*$ & $*$ & * \\
\hline & $\mathrm{Kp}$ & $* *$ & $*$ & * & * \\
\hline & Sg & * & $*$ & * & * \\
\hline & Sf & * & $*$ & $* *$ & * \\
\hline \multirow[t]{3}{*}{ Ec } & $\mathrm{Kp}$ & $* *$ & $*$ & $*$ & $*$ \\
\hline & Sg & $* *$ & $* *$ & $*$ & $*$ \\
\hline & Sf & $* *$ & $* *$ & $*$ & $*$ \\
\hline \multirow[t]{2}{*}{$\mathrm{Kp}$} & Sg & $* *$ & $*$ & $*$ & $*$ \\
\hline & Sf & ** & * & * & * \\
\hline $\mathrm{Sg}$ & $\mathrm{Sf}$ & $* *$ & $* *$ & $* *$ & $* *$ \\
\hline $\begin{array}{l}{ }^{*} \text { Sign } \\
\text { Sm, S } \\
\text { coli; } \mathrm{K} \\
\text { faecal }\end{array}$ & $\begin{array}{l}\text { tt; *x } \\
\text { ylocc } \\
\text { ebsie }\end{array}$ & $\begin{array}{l}\text { ignificant. } \\
\text { nutants; Sa, St } \\
\text { umonia; Sg, Str }\end{array}$ & $\begin{array}{l}\text { coccus } \\
\text { ccus } g\end{array}$ & $\begin{array}{l}\text { eus; } \\
\text { us; Sf, }\end{array}$ & $\begin{array}{l}\text { heric } \\
\text { ococ }\end{array}$ \\
\hline
\end{tabular}

Table 1. The significance of different Punica granatum extracts among tested extracts

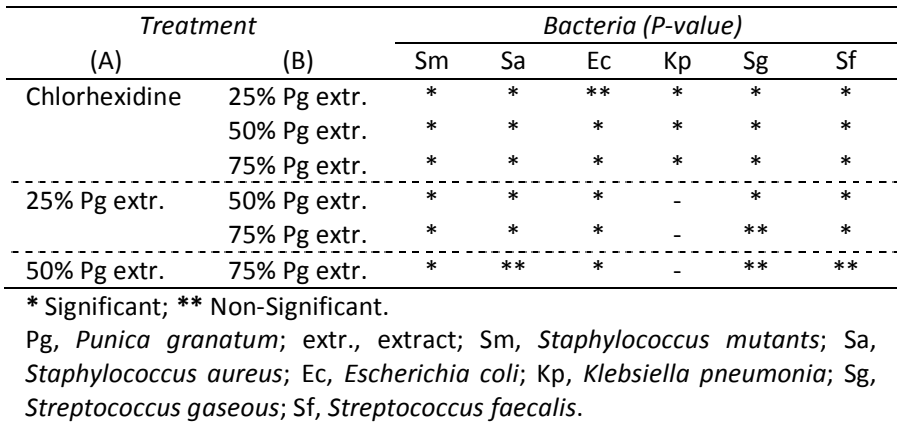

\section{Conclusion}

The results of the present study could verify the antibacterial potential of pomegranate and its use as traditional medicine. Pomegranate peels may have used in alternative health therapies; including medicines derived from plants, which have the advantages of being easily available and cheaper than modern medicines. However, further studies using different solvents are needed to estimate the antimicrobial effect of pomegranate.

\section{Study Limitation}

The present study results could verify the antibacterial potential of pomegranate extracts and it uses as an alternative, cheap and traditional mouthwash than modern ones. However, Clinical application was needed to support the role of pomegranate extracts as an antimicrobial mouthwash.

\section{Conflict of interest}

Authors are the only researchers that responsible and self funded for this paper manuscript. We are the author's state that the manuscript for this paper is original, and it has not been published previously and is not 
under consideration for publication elsewhere, and that the final version has been seen and approved by all authors.

\section{References}

1. Vinatoru M. An overview of the ultrasonically assisted extraction of bioactive principles from herbs. Ultrason Sonochem 2001. 8(3): p. 303313. https://doi.org/10.1016/S1350-4177(01)00071-2.

2. Modak M, Dixit P, Londhe J, Ghaskadbi S, Devasagayam TP. Indian herbs and herbal drugs used for the treatment of diabetes. J Clin Biochem Nutr 2007; 40(3): 163-173. http://doi.org/10.3164/icbn.40.163.

3. Dipak G, Axay P, Manodeep C, Jagdish KV. Phytochemical and pharmacological profile of Punica granatum. International Journal of

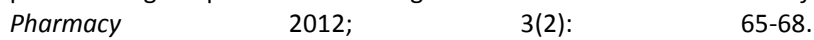
http://www.iriponline.com/admin/php/uploads/841 pdf.pdf.

4. Prashanth D, Asha M, Amit A. Antibacterial activity of Punica granatum. Fitoterapia 2001; 72(2): 171-173. https://doi.org/10.1016/S0367-326X(00)00270-7.

5. Jurenka JS. Therapeutic applications of pomegranate (Punica granatum L.): a review. Altern Med Rev 2008; 13(2): 128-144. https://www.ncbi.nlm.nih.gov/pubmed/18590349.

6. Al-Zoreky NS. Antimicrobial activity of pomegranate (Punica granatum L.) fruit peels. Int J Food Microbiol 2009; 134(3): 244-248. https://doi.org/10.1016/i.ijfoodmicro.2009.07.002.

7. Dahham SS, Ali MN, Tabassum H, Khan M. Studies on antibacterial and antifungal activity of pomegranate (Punica granatum L.). Am-Euras $J$ Agric \& Environ Sci 2010; 9(3): 273-281.

8. Sánchez-Lamar A, Fonseca G, Fuentes JL, Cozzi R, Cundari E, Fiore M, et al. Assessment of the genotoxic risk of Punica granatum L. (Punicaceae) whole fruit extracts. J Ethnopharmacol 2008; 115(3): 416422. https://doi.org/10.1016/j.jep.2007.10.011.

9. Naqvi S, Khan M, Vohora S. Anti-bacterial, anti-fungal and anthelmintic investigations on Indian medicinal plants. Fitoterapia 1991; 62: 221228.

10. Frawley D, Lad V. The yoga of herbs: an ayurvedic guide to herbal medicine. Motilal Banarsidass Publ, 1994.

11. Saxena M, Saxena J, Nema R, Singh D, Gupta A. Phytochemistry of medicinal plants. Journal of Pharmacognosy and Phytochemistry 2013; 1(6): 168-182. http://www.phytojournal.com/vol1Issue6/Issue_march_2013/26.pdf.

12. Ali SI, El-Baz FK, El-Emary GAE, Khan EA, Mohamed AA. HPLC-analysis of polyphenolic compounds and free radical scavenging activity of pomegranate fruit (Punica granatum L.). Int J Pharm Clin Res 2014; 6(4): 348-355. http://palepmrf.com/pdf/MeOH-extract-Pomegranatepeel.pdf.

13. Saad EA, Hassanien MM, El-Hagrasy MA, Radwan KH. Antidiabetic, hypolipidemic and antioxidant activities and protective effects of Punica granatum peels powder against pancreatic and hepatic tissues injuries in streptozotocin induced IDDM in rats. Int J Pharm Pharm Sci 2015; 7(7): 397402.

https://innovareacademics.in/journals/index.php/ijpps/article/viewFile/67 $\underline{05 / 2649 .}$.

14. Murthy KN, Reddy VK, Veigas JM, Murthy UD. Study on wound healing activity of Punica granatum peel. J Med Food 2004; 7(2): 256-259. https://doi.org/10.1089/1096620041224111.

15. Hoffmann D. The complete illustrated holistic herbal: a safe and practical guide to making and using herbal remedies. Shaftesbury, Dorset: Element Books, 1996; 256 p.

16. Henley E, Uttech K, Wenzel-Wamhoff J. PDR for herbal medicines. Journal of Family Practice 1999; 48(5): 390.

17. PDR for herbal medicines. 4th Edition. Thomson PDR, 2007; 1250 p.

18. Ibrahium M. Efficiency of pomegranate peel extract as antimicrobial, antioxidant and protective agents. World Journal of Agricultural Sciences 2010; 6(4): 338-344. https://www.idosi.org/wjas/wjas6(4)/1.pdf.
19. Duman AD, Ozgen M, Dayisoylu KS, Erbil N, Durgac C. Antimicrobial activity of six pomegranate (Punica granatum L.) varieties and their relation to some of their pomological and phytonutrient characteristics. Molecules 2009; 14(5): 1808-1817. https://doi.org/10.3390/molecules14051808.

20. Hamady GA, Abdel-Moneim MA, El-Chaghaby GA, Abd-El-Ghany ZM, Hassanin MS. Effect of pomegranate peel extract as natural growth promoter on the productive performance and intestinal microbiota of broiler chickens. African Journal of Agricultural Science and Technology (AJAST) 2015; 3(12): 514-519. https://www.oceanicjournals.com/ajast/abstract/2015/December/Ma mdouh\%20\%20et\%20al..htm.

21. Chebaibi A, Filali R. Bactericidal activity and phytochemical screening of Moroccan pomegranate (Punica granatum Linn.) peel aqueous extracts. J Med Plants Res 2013; 7: 887-891. https://doi.org/10.5897/JMPR12.988.

22. Sharma R, Saxena R, Nandy BC. Extraction of bioactive chemical compounds and antibacterial activity of biowaste fruit peels extract of punica granatum. Journal of Biomedical and Pharmaceutical Research 2016; 4(5): 53-61. http://jbpr.in/index.php/jbpr/article/view/489.

23. Lansky EP, Newman RA. Punica granatum (pomegranate) and its potential for prevention and treatment of inflammation and cancer. $J$ Ethnopharmacol 2007; 109(2): 177-206. https://doi.org/10.1016/i.jep.2006.09.006.

24. Mathabe MC, Nikolova RV, Lall N, Nyazema NZ. Antibacterial activities of medicinal plants used for the treatment of diarrhoea in Limpopo Province, South Africa. J Ethnopharmacol 2006; 105(1): 286-293. https://doi.org/10.1016/i.jep.2006.01.029.

25. Zaidan MR, Noor Rain A, Badrul AR, Adlin A, Norazah A, Zakiah I. In vitro screening of five local medicinal plants for antibacterial activity using disc diffusion method. Trop Biomed 2005; 22(2): 165-170. https://www.ncbi.nlm.nih.gov/pubmed/16883283.

26. Tepe B, Daferera D, Sokmen A, Sokmen M, Polissiou M. Antimicrobial and antioxidant activities of the essential oil and various extracts of Salvia tomentosa Miller (Lamiaceae). Food Chemistry 2005; 90(3): 333340. https://doi.org/10.1016/j.foodchem.2003.09.013.

27. Aneja KR, Joshi R, Sharma C. The antimicrobial potential of ten often used mouthwashes against four dental caries pathogens. Jundishapur Journal of Microbiology 2010; 3(1): 15-27. http://jim.ajums.ac.ir/ jjm/documents/15-27JR.pdf.

28. Dasgupta N, Ranjan S, Saha P, Jain R, Malhotra S, Arabi Mohamed Saleh MA. Antibacterial activity of leaf extract of Mexican marigold (Tagetes erecta) against different gram positive and gram negative bacterial strains. J Pharm Res 2012; 5(8): 4201-4203. http://iprsolutions.info/files/final-file-57944be92c4dd0.83730986.pdf.

29. Santoso S. SPSS 22 from essential to expert skills. Jakarta: PT Elex Media Komputindo, 2014.

30. Cáceres A, Girón LM, Alvarado SR, Torres MF. Screening of antimicrobial activity of plants popularly used in Guatemala for the treatment of dermatomucosal diseases. J Ethnopharmacol 1987; 20(3): 223-237. https://doi.org/10.1016/0378-8741(87)90050-X.

31. Ram AJ, Bhakshu LM, Raju RV. In vitro antimicrobial activity of certain medicinal plants from Eastern Ghats, India, used for skin diseases. J Ethnopharmacol 2004; 90(2): 353-357. https://doi.org/10.1016/j.jep.2003.10.013.

32. Gebre-Mariam T, Neubert R, Schmidt PC, Wutzler P, Schmidtke M. Antiviral activities of some Ethiopian medicinal plants used for the treatment of dermatological disorders. J Ethnopharmacol 2006. 104(1): 182-187. https://doi.org/10.1016/j.jep.2005.08.071.

33. Sandhya B, Thomas S, Isabel W, Shenbagarathai R. Ethnomedicinal plants used by the valaiyan community of Piranmalai Hill (Reserved Forest) Tamilnadu India.-A pilot study. African Journal of Traditional Complementary and Alternative Medicines 2016; 3(1): 101-114. http://journals.sfu.ca/africanem/index.php/ajtcam/article/view/12. 
34. Cerdá B, Espín JC, Parra S, Martínez P, Tomás-Barberán FA. The potent in vitro antioxidant ellagitannins from pomegranate juice are metabolised into bioavailable but poor antioxidant hydroxy-6Hdibenzopyran-6-one derivatives by the colonic microflora of healthy humans. Eur J Nutr 2004; 43(4): 205-220. https://doi.org/10.1007/s00394-004-0461-7.

35. Tesaki S, Tanabe S, Moriyama M, Fukushi E, Kawabata J, Watanabe M. Isolation and identification of an antibacterial compound from grape and its application to foods. Journal of the Agricultural Chemical Society of Japan (Japan) 1999; 73(2): 125-128. https://doi.org/10.1271/nogeikagaku1924.73.125.

36. Scalbert A. Antimicrobial properties of tannins. Phytochemistry 1991; 30(12): 3875-3883. https://doi.org/10.1016/0031-9422(91)83426-L.

37. Shan B, Cai YZ, Brooks JD, Corke H. The in vitro antibacterial activity of dietary spice and medicinal herb extracts. Int J Food Microbiol 2007; 117(1): 112-119. https://doi.org/10.1016/j.ijfoodmicro.2007.03.003.

Authors:

Dhifaf M. Al-Obaidi - MSc \& BSc (Prosthetic Dental Technology), Lecturer, Department of Biomedical Engineering, Al-Khawarizmi College of Engineering, Baghdad University, Baghdad, Iraq. http://orcid.org/00000003-4433-569x.

Saja Ali Muhsin - PhD (Restorative Dentistry), MSc \& BSc (Prosthetic Dental Technology), Lecturer and Postgraduate Tutor, Department of Prosthtic Dental Technology, College of Health and Medical Technology, Middle Technical University (MTU), Baghdad, Iraq. http://orcid.org/00000003-0272-7409.

Afnan A. Ibrahim - MSc (Pharmacology), Market Research and Consumer Protection Centre, Baghdad University, Baghdad, Iraq. http://orcid.org/0000-0002-1917-3011. 